Thermal Insulation (Industrial Buildings) Act of July 1957 to all new dwelling houses built in the United Kingdom after 1959. Mr. Nabarro said that on the evidence of the Egerton Committee's report of 1946 and of the Ridley Committee's report of 1952 we used on average five tons of coal or its equivalent per dwelling per annum, of which four tons were used for space- and water-heating services generally. He claimed that at least 25 per cent of this would be saved by proper insulation of houses. Accordingly, at an annual construction of 250,000 houses, an initial saving of 250,000 tons should be achieved, rising progressively to 5 million tons per annum at the end of twenty years. The minimum economy of $£ 40$ million per annum, at to-day's price, made investment in thermal insulation, which should not cost more than $£ 8$ on a $£ 1,600$ four-bedroom council house, well worth while.

\section{Stars Month by Month}

THERE are many people who have a general interest in the phenomena of the night sky and who need a simpler description of the visibility of the stars and planets than is found in the almanacs. To meet this need The Times produces an annual booklet. The latest edition, "The Night Sky 1958" (pp. 27. London : The Times Publishing Co., Ltd., 1958. 3s. net), gives charts for every month of 1958. Each chart shows the sky as it appears at 11 p.m. on the first day of the month together with the positions of the moon and planets. Each chart is accompanied by notes on the visibility of the planets and the phases of the moon for the month. There are notes on the eclipses which occur during the year, and some general explanatory notes. The booklet is well produced and the information which it contains clearly presented. The booklet is suitable not only for the general public but also for use by those schools, societies and clubs in which efforts are made to introduce young people to the phenomena of Nature.

Bishop's Stortford School Natural History Society

THE value of school natural history societies and the contribution they can make to new knowledge is illustrated by the activity of the Bishop's Stortford College Natural History Society. Observations on the mistletoe by a senior boy, D. J. Cove, were noted in Nature $(178,779 ; 1956)$, and will now be included by the Forestry Commission in a new book on the diseases of forest trees. Besides the usual sectional reports, the latest issue of the Society's journal, Coturnix, contains details of studies on the larger fungi of the Bishop's Stortford district by J. W. Neal and the distribution of certain myriapods and crustaceans in organic debris during the winter months by M. Morton. Interesting observations on the reactions of certain myriapods to light, gravity, certain smells, water and oxygen were made by J. G. Pickard, who was able to show that the relatively high rate of respiration of the lithobiomorph centipede may be correlated with its observed restlessness ; the low rate in the case of Julus with its observed sluggishness. A regional survey of the local sewage farm was made by R. G. Oakley, while P. H. King made continuous observations at Mersea Island, the centre of the oyster industry.

\section{Extension of Primary Cell Walls}

THE mechanism of deposition and extension of primary cell walls has been further investigated by G. Setterfield and S. T. Bayley (Canadian J. Bot.,
35,435 ; 1957). Walls of elongating parenchyma and epidermal cells of Avena coleoptiles and onion roots were studied by autoradiography, using sugars labelled with carbon-14, and by electron microscopy of thin transverse sections. The autoradiographs showed that deposition of cellulose takes place over the whole length of the cell, ruling out the possibility of bipolar tip growth. Autoradiographs of cells grown for short periods in labelled sugar gave no evidence of localized incorporation of the isotope around primary pit-fields, but rather indicated that deposition of microfibrils is finely dispersed over the entire wall surface. The thin sections reverled a marked change in wall structure as elongation proceeds. Walls of young cells contain only transversely oriented microfibrils, while older walls include an inner region of predominantly transversely oriented microfibrils bounded outside by a region with microfibrils showing an irregular transition to longitudinal orientation. The degree of longitudinal orientation in the outer region increases with length of cell. These results for thin walls are consistent with the multi. net model for wall growth deduced by other workers from electron microscope studies on cell fragments. Thin sections have also revealed layering in several types of growing walls which is difficult to interpret on the basis of the multi-net model alone.

\section{Graft Unions between Meristematic Tissues}

UNDER the title of "The Regeneration of Severed Pea Apices", H. F. Gulline and R. Walker (Australian J. Bot., 5, 129; 1957) have described successful graft unions between meristematic tissues in apices of the pea, Pisum sativum L. A technique for preventing desiccation of apices during and after the operations is described. Apical segments ranging from about $200 \mu$ down to $50 \mu$ in depth were successfully grafted back to their parent plant. The subsequent development of grafted apices was completely normal. These experiments show that a complete shoot can be regenerated from an apical segment less than onethousandth of a cubic millimetre in volume, con. taining about 600 cells. This is smaller than any graft previously recorded. The morphogenetic interest of this investigation needs no emphasis.

\section{U.K. Atomic Energy Authority: Appointments}

Dr. H. Kronberger has been appointed director of research and development at the Industrial Group Headquarters at Risley, Lancashire, of the United Kingdom Atomio Energy Authority. He succeeds Mr. L. Rotherham, whose appointment as a member of the Central Electricity Generating Board was announced in Nature of January 4, p. 20. Dr. Kronberger, who is thirty-eight years of age, was chief physicist at Risley prior to his new appointment.

Mr. J. C. C. Stewart, formerly director of technical policy in the Industrial Group at Risley, becomes a deputy managing director of the Industrial Group. Mr. J. B. W. Cunningham, formerly deputy director (civil reactors), becomes director of industriel power in the Industrial Group. Dr. R. Hurst, formerly chief chemist in the Research and Development Branch of the Industrial Group at Risley, becomes director of the Dounreay Experimental Reactor Establishment. Mr. D. S. Mitchell, formerly director of administration, becomes director of personnel and administration in the Industrial Group. These appointments, which took effect on February 1, mark a first stage towards implementing recom- 